\title{
Investigation of application of storm runoff harvesting system using geographic information systems (GIS): a case study of the Arak watershed, Markazi (Iran)
}

\author{
J. Varvani ${ }^{1}$ M. R. Khaleghi ${ }^{2}$
}

Received: 7 June 2018 / Accepted: 19 September 2018 / Published online: 25 September 2018

(c) The Author(s) 2018

\begin{abstract}
Integrated management of urban watersheds and effective productivity of its resources, especially water resources, requires knowledge of its hydrology. In this regard, flood events and urban runoff produced at the time of floods from the point of harvesting and consumption of critical are very important. In this study in order to evaluate the possibility of using the most appropriate rainwater harvesting systems in Arak watershed, by collecting basic information from the watershed overlooking the city, surrounding watersheds were grouped by using the cluster analysis in homogeneous areas. In each region using the soil conservation service model, the rate of base time and return periods was calculated. Also, using an analytic hierarchy process and quantitative and qualitative criteria, different systems of urban water harvesting were determined for each homogeneous region of Arak watershed.
\end{abstract}

Keywords Rainwater harvesting systems $\cdot$ Flood $\cdot$ Urbanized watershed $\cdot$ Analytical hierarchy process

\section{Introduction}

The largest environmental challenge that Iran and humankind in the world face today is the scarcity of water (Vialle et al. 2011, 2012; Zhang et al. 2014). This phenomenon, especially in Iran, seems to be due to climatic conditions, such as aridity and abundance of high solar radiation and by population pressure. Iran is one of the ten most waterdeprived countries in the world, and also is the second largest country in the Middle East, and its average annual rainfall is $240 \mathrm{~mm}$, which is less than one-third of the global average value, making the region among the world's driest regions. Recent studies in Iran have shown that the total volume of annual precipitation is almost 430 billion $\mathrm{m}^{3}$, but

\section{R. Khaleghi}

drmrkhaleghi@gmail.com

J. Varvani

varvani_55@yahoo.com

1 Department of Range and Watershed Management, Arak Branch, Islamic Azad University, Arak, Iran

2 Department of Range and Watershed Management, Torbat-e-Jam Branch, Islamic Azad University, Torbat-e-Jam, Iran that more than $20 \%$ is lost in the form of flash floods (Foltz 2002; Khaleghi et al. 2011). Unfortunately, current water use already in Iran exceeds renewable supply remarkably, and thus, it is necessary to find various and alternative sources of water to increase the sources of water supply, such as RWHSs (rainwater that falls onto rooftop of buildings and is collected directly into a rain storage tank) that is the most directly accessible water resources (Jones and Hunt 2010; Khaleghi and Varvani 2018a, b). Thus, scientific planning and management are needed to use rainwater efficiently (Khaleghi et al. 2011; Youn et al. 2012; Khaleghi et al. 2014). The watershed management approach is as a fundamental principle in the ecology of the ecosystem which takes into account to make a relationship between basic and applied sciences. Achieving this approach involves an integrative management combined with the holistic, accurate and fair approach in relation to internal and external processes of watershed which eventually lead to a sustainable ecosystem. In a comprehensive approach to the watershed, the base of management is guiding to the hydrology. Because of increased runoff, in addition to causing flooding damage, types of pointers (specific) and nonpoint source (NPS) pollution, such as depositions, pesticides, heavy metals, salts and chemical materials, increase and seriously endanger the health of the accumulation environment. NPS pollution 
refers to both water and air pollution from diffuse sources. According to Vijayaraghavan et al. (2012) and other limited literature on runoff quality assessment, urban runoffs are often regarded as a source of contaminants (Moran et al. 2003; Berndtsson et al. 2006; Teemusk and Mander 2007; Berndtsson 2010). In recent decades, in the framework of a comprehensive management, the urban watersheds have been considered from the standpoint of good urban governance and interactions with environmental conditions (Groffman et al. 2004). Thus, the correct approach in the management of urban runoff is necessarily based on a combination of purposes and strategies. The US Environmental Protection Agency (EPA), in the assessment of urban runoff and to describe of sustainable water resource management, uses the concepts of "Low Impact Development" (LID) and green infrastructures that emphasis on importance of using Best Management Practice (BMP) that from point of concept encompasses a wide variety of appropriate technologies and activities intended to minimize the effect of watershed development on flow regimes without altering riparian morphology (Perez-Pedini et al. 2005); Sustainable Urban Drainage Systems (SUDS) and of Storm-water Source Controls (SSCs), that these RWHSs effectively take "offline" individual micro-catchments within urban service areas could be the key solutions to alleviate these heavy burdens (Roy et al. 2008). The benefits of RWHSs as a multi-beneficial strategy are reduced and delay of runoff volume and flow peak discharge, increased groundwater recharge, reduced runoff pollution, increased decomposition of carbon, reduction in heating energy, improve air quality, aquatic habitat, wildlife and recreation, improving human health and adding value lands (Morton 2002; Muthukrishnan et al. 2004; Platt 2006; Foundation 2008). BMPs in relation to LID include structural controls such as infiltration devices, ponds, filters and constructed wetlands, and non-structural controls such as maintenance practices, street sweeping, public education and outreach programs (Muthukrishnan et al. 2004). RWHS as a viable means of closing and more sustainably managing urban water resource cycles (Daigger 2009) and as one of the tools of SUDS which aim at restoring the natural hydrologic cycle in the urban environment (Palla et al. 2011) and as a strategy that brings many benefits and may serve to cope with current water shortages, urban stream degradation and flooding (Fletcher et al. 2008; Van Roon 2007; Zhu et al. 2004; Farreny et al. 2011) which belongs to building the controls that have been used extensively according to water resources management and environmental monitoring programs. These systems are increasingly becoming an integral part of the sustainable storm-water (rainwater that falls onto catchment areas) management toolkit (Butler et al. 2010; Ward et al. 2012). Also, as an ancient technique (Boers and Asher 1982) consists of a set of measures that form of collection and use of rainwater from impervious surfaces such as roofs, earth's surface, road surface or watersheds with low permeability (rock) (Obeidat and Awawdeh 2002). To select an RWHS system according to LID and supervising on executions, it is necessary to do various researches in the context of integrated watershed management. However, increasing the implementation of runoff harvesting, without encountering unintended impacts on downstream hydrological and ecological systems, requires a better understanding of the hydrology and environmental impacts at catchment scale (De Winnaar et al. 2007). Much research has been conducted by various researchers in the field by selecting the type of RWHS, performance, socioeconomic issues and the effects of these systems. Designing an RWHS often balances conflicting goals, such as reducing runoff volume, providing a reliable water supply and minimizing system costs (Jones and Hunt 2010). Abdulla and Al-Shareef (2009) believe that RWHSs can promote significant water saving in residences in different countries. Also, the most attractions of these systems are the low cost, accessibility and easy maintenance at the household level. Contour furrow and protective terraces, mulches, water tanks, gabion and dry-stone drainages, permeable basins and band filters are considered among these systems that have a large contribution to the collection and convey runoff from storm events, especially in urban areas. Also in agriculture, RWHSs systems have an important role in supplemental irrigation in order to increase agricultural productions and improve livelihoods in dry areas (Oweis and Hachum 2006). Runoff behavior is very important for the successful design of the RWHSs that is one of the water recovery alternatives ( $\mathrm{Li}$ et al. 2004). In other words, the most common methodology for the design of RWHSs is the behavioral analysis that uses continuous simulation to assess the inflow, outflow and change in the storage volume of the RWHSs according to a mass balance equation (Mitchell 2007; Liaw and Tsai 2004; Palla et al. 2011). The temporal storage of water in the soil and vegetation reduces peak flow, which prolongs the time of concentration. Also, any reduction in the peak flow of local runoff results in considerable reduction in local urban flooding and combined sewer overflows (Vijayaraghavan et al. 2012). Mwenge Kahinda et al. (2008) indicated that recently, the potential of RWHSs to mitigate the variability of rainfall (spatially and temporally) becomes very obvious. Ahmed et al. (2007) proved the effectiveness of AHP in combination with GIS for analyzing the site suitability for RWHSs in the arid zone of Northern Mauritania (Oasis area). Recent studies, although performedusing a variety of different methods, suggest that potential potable water savings from these practices could be significant. For example, Hermann and Schmida (1999) estimated that the average household could reduce potable water demand by 30-60\% using roof runoff harvested in a $4-6 \mathrm{~m}^{3}$ tank for toilet flushing. Zhang et al. (2009) observed that harvesting all roof runoff for use in 
toilet flushing can reduce potable water consumption in residential buildings by about $25 \%$. The researchers such as De Winnaar et al. (2007) and Ziadat et al. (2012) have used GIS and remote sensing (RS) to locate sites suitable for macrocatchment RWHS schemes. James Grant et al. (2018) used an approach to quantifying rainwater harvesting potential using imagery, GIS and LiDAR data (Light Detection and Ranging - is an RS method used to examine the surface of the Earth).

Above-mentioned results show that RWHSs is one of the best available methods for establishing the sustainable water cycles in urban developments (Lee et al. 2012; Lye 2009; Kim et al. 2005). Also, according to results from the literature, it can be seen that RWHSs are a perfect complement source, both for agriculture and for urban water networks, and their use is growing in arid and semiarid regions. The Arak urban watershed is one of the areas that is faced with water quality and quantity problems due to population growth and increased industries. Drought in recent years, the indiscriminate withdrawal of groundwater, unauthorized wells, non-systematic and unprocessed disposal of wastes (garbage) and the penetration of its effluent into groundwater aquifers have made it difficult for the city's water supply. On the other hand, the water transfer project from the Kamal Saleh Dam watershed is not considered as a long-term water supply for all households in the Arak city.

Due to the high cost of this project, the excessive use of this water source is not reasonable for non-potable uses. Hence, the use of RWHSs can be used as a supplemental source of water supply for the city. The main objective of this study was to determine the most suitable RWHSs for watersheds as a supplemental water supply source of Arak city. Given the importance of this research, using AHP and with Expert Choice software, the most appropriate RWHSs prioritized for homogeneous watersheds adjacent to the city, in addition to achieving the primary goal, to have a proper management of water resources related to watersheds overlooking to the city.

\section{Materials and methods}

\section{Description of the study area}

The study area, in Markazi province, consisted of approximately $70 \mathrm{~km}^{2}$ located between $34^{\circ} 4^{\prime}$ and $34^{\circ} 12^{\prime}$ West-East longitudes and 49 $36^{\prime}$ and $49^{\circ} 48^{\prime}$ North-South latitudes (Fig. 1). The climate based on the De Martonne method is semiarid and based on Emberger method is semiarid and cold. Therefore, the rainfall regime is irregular. According to observations result in 32 yearly in Markazi province, the mean annual temperature is $13.8^{\circ} \mathrm{C}$. The annual precipitation of the area is $320.2 \mathrm{~mm}$, and precipitations disperse every month non-symmetrically. The topography of the study area varies between 1840 and $3300 \mathrm{~m}$, and the dominant range in elevation is $1900-2100 \mathrm{~m}$. The dominant range in elevation is $1840-2350 \mathrm{~m}$. The mainstream is the Kerahrud River, which originates from Qara-Kahriz uplands and flows to Mighan wetland, after passing the Arak city. This study was carried out during 2010-2012 on the development of the arid environment.

\section{Methodology}

Most studies on watershed runoff occur within the framework of hydrologic units. For this purpose, hydrological unit's boundary overlooking the city was drawn on topographic maps with the scale of 1:25,000 in GIS environment using ArcGIS software. According to the purpose of this study, city boundary of Arak is also introduced as a separate unit so that the calculations will be performed with high precision in urban hydrology. On this basis, the 16 watersheds were identified.

\section{Classification of homogeneous watersheds}

Due to a large number of watersheds overlooking the Arak city and also due to the production of appropriate information resulting from this research as a group, an attempt was made to the grouping of homogeneous watersheds with the cluster analysis. For this purpose, metric independent variables such as area, average slope, minimum and maximum height, the percentage area of different land-use and hydrologic soil groups were used as the basis cluster analysis. Then, the quantitative values of these variables were entered into the software SPSS15.0 and classification of watersheds was made based on them. Table 1 shows the physiographic characteristics and land use related to the different understudy watersheds. Physiographic properties include area and average height. Also, land-use features include the area of each land-use and the hydrological group of the soil.

\section{Calculation of the volume of runoff related to design storm}

For further investigation in selection of suitable RWHSs and given that various systems should be capable of producing the volume of runoff during a day with a high probability, and hence, the maximum 24-hour precipitation with a return period of 100 years was considered as a design rainfall and the height of the runoff resulted from this rainfall was calculated according to the SCS method in which each watershed area was of 100 square meters. It should be noted that the rate of design rainfall was earned according to Intensity-Duration-Frequency (IDF) curves

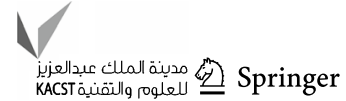


Fig. 1 The position watersheds overlooking the Arak city

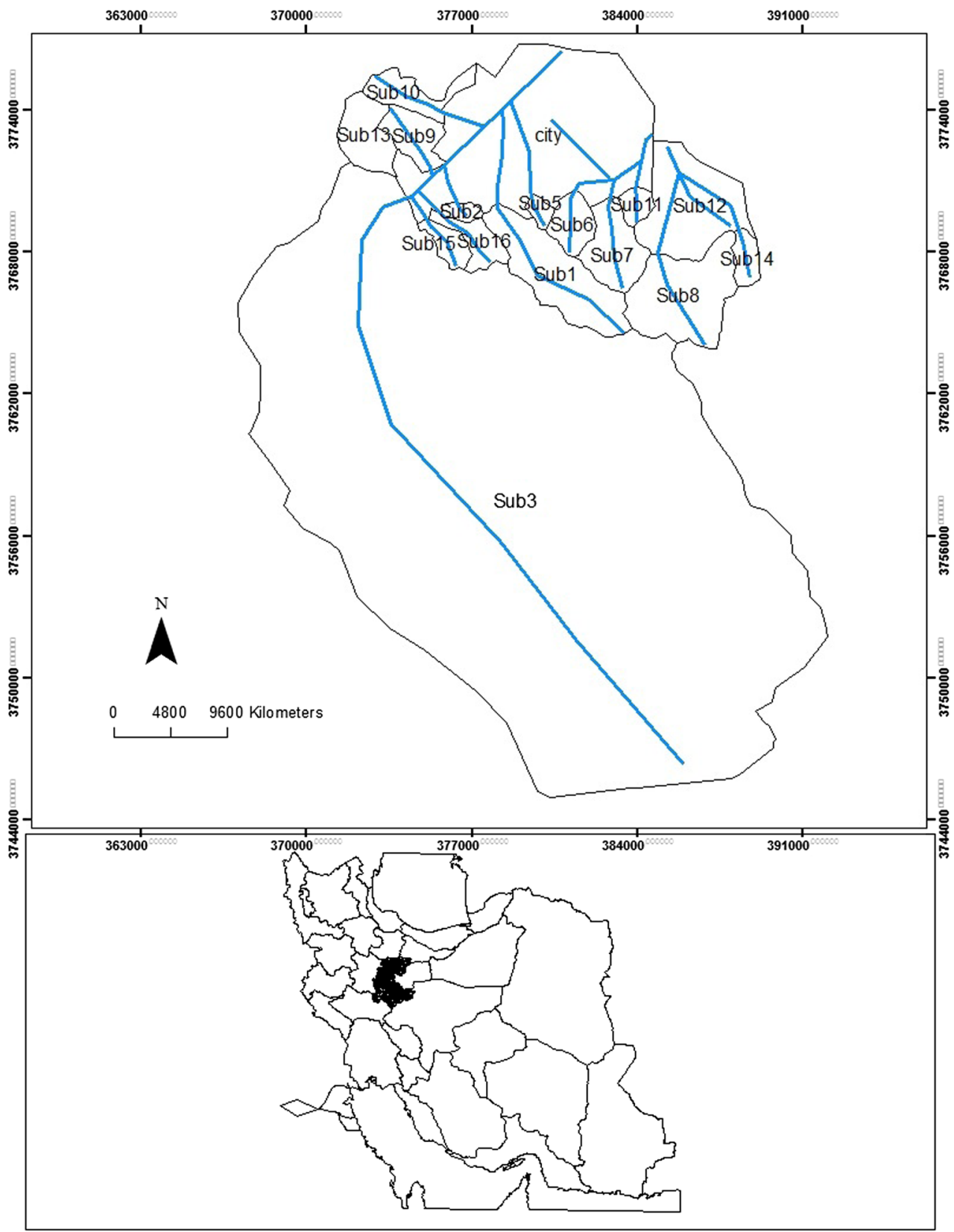

and rainfall hyetograph years 1973-2003 of the Arak Synoptic station. The rates of curve number $(\mathrm{CN})$ related to study area were determined based on cells map of 100 in 100 meters and using the layers of land-use and soil hydrologic groups (Fig. 2). Maps required by this section such as land-use and soil hydrologic groups were prepared based on basic studies in the watershed area and field controls (Jihad 2009). Finally, the volume of design storm was calculated based on the runoff height and the area of each watershed.

\section{Determination of the options and assessment criteria}

In this study, to make the correct decisions in selecting the most appropriate system for heterogeneous watersheds, AHP process using the EXPERT CHOICE11 software was used. 


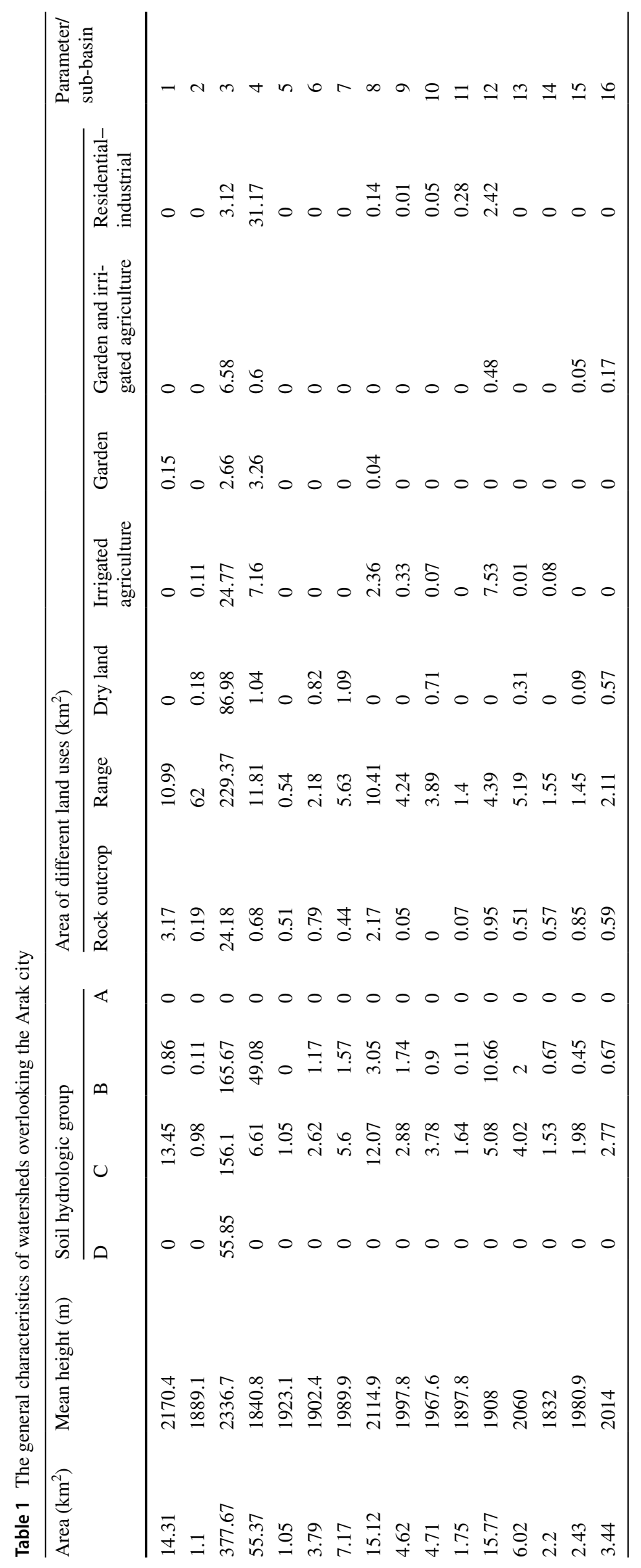


Fig. $2 \mathrm{CN}$ layer and its values in the watersheds overlooking the Arak city

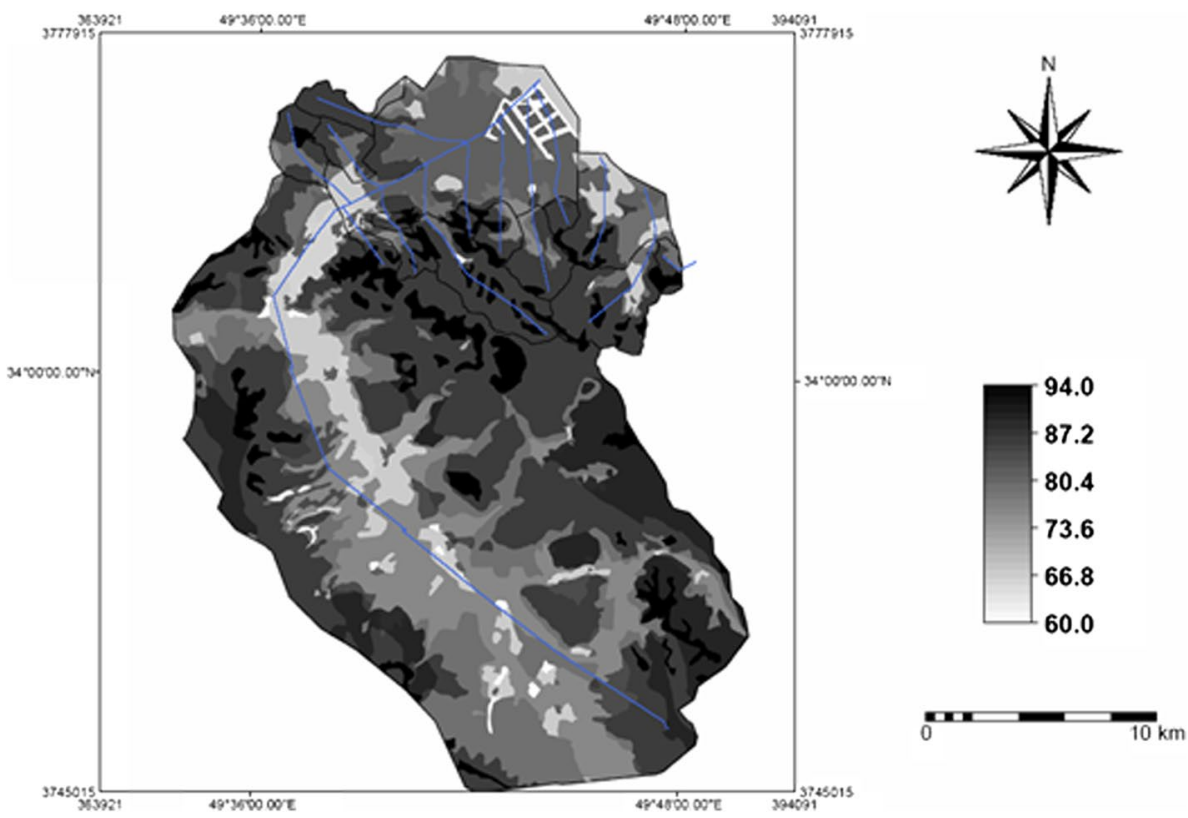

\section{AHP evaluation of weighting values}

The AHP improved by Saaty (1980) that supplies a flexible and easily understood way of analyzing complicated problems. The AHP is a multi-objective, multi-criteria decisionmaking approach that enables the user to arrive at a scale of preferences drawn from a set of alternatives. The AHP is a problem-solving construction and a methodical process for representing the elements of any problem (Saaty and Vargas 1991; Yalcin et al. 2011).

The AHP has shown that weighting activities in multicriteria decision-making can be effectively dealt with via hierarchical and pairwise comparisons (Singh 2009). This method was selected because of its applicability in decisions involving multi-criteria. It uses both quantitative and qualitative data and the availability of ample literature describing its method (Ahmed et al. 2007). The AHP was conducted using the following three steps: (a) identification of the decision elements; (b) construction of an importance table and finally, (c) computing the relative weights. To apply this approach, it is necessary to break a complex unstructured problem down into its component factors; arrange these factors in a hierarchial order; assign numerical values to subjective judgments on the relative importance of each factor; and synthesize the judgments to determine the priorities to be assigned to these factors (Saaty and Vargas 2001; Yalcin et al. 2011). After formation of the matrix, the sum of each column for all of the parameters is written below the matrix. Then in order to calculate the weight of each parameter, the value of each parameter of the matrix is divided by the sum of columns of the same layer and put in the other table. In the resulted table, the average of rows is considered as the weight of each layer. The rate of each class of parameters will be determined in the next stage. To do this, the distribution map of landslides overlays on different layers and the percent of slide area calculated in each class (Teimouri and Graee 2012). For this purpose, first, according to the study area and according to the previous studies in the area (Reports of collating, synthesize and social and economic, Jihad 2009) and recommendations made in this field, five options for RWHS were selected at different levels such as existing situation, Micro Basin, Water Tank, French Drain, and Mulch. In order to select the best available option, it was considered that three quantitative criteria include the initial investment (execution cost), the efficiency of RWHSs (the rate of benefit to cost ratio) and maintenance costs and two qualitative criteria include ease of implementation and water extraction capability. In order to carry out the AHP and to weigh the criteria and different systems of water extraction, the quantitative criteria were first calculated for all water extraction options (RWHSs) and in all homogeneous groups. Qualitative criteria also were converted to a quantitative value according to expert judgment. It should be noted that water harvesting in Micro Basin, Water Tank, and French Drain was considered in terms of 1 cubic meter and also in Mulch was considered in terms of 1 square meter. After determining the values of quantitative and qualitative criteria related to all of proposed RWHSs, the related data for each homogeneous group were entered into an EXPERT CHOICE11 software and with the help of this software, for each homogeneous group, the best choice was selected from five considered options. Finally, these selective systems were evaluated according to the characteristics of heterogeneous watersheds. 


\section{Results}

In this research, the base of decision-making is a homogenous category of watersheds. Hence, five homogeneous groups were determined using cluster analysis. It should be noted that Arak urban watershed together with watershed number 2 is located in group 2. Table 2 shows the results of the grouping of homogeneous watersheds. These homogeneous groups were distinguished based on statistical tests. In general, the studied areas were classified into 5 homogeneous groups.

To calculate the runoff volume by SCS method, the rate of design storm (the maximum 24-hour precipitation with a return period of 100 years) based on Intensity-Duration-Frequency curves of the Arak Synoptic station was determined to equal to $67.7 \mathrm{~mm}$.

Table 3 presents the total surface runoff volume calculated for each watershed area and for one hectare.

As noted previously, to the running of AHP and to the weighting of criteria and various RWH, first quantitative measures were calculated for all of RWHS options and in all of the homogeneous groups. The first option that is the acceptance of existing conditions, certainly any system is not running and it is obvious that there is no cost. Therefore, this measure is calculated for four alternatives. Table 4 shows the result of the amount of initial investment required by each of the executive or RWHS options.

To calculate the efficiency of RWHSs, first benefits from the implementation of various systems given the amount of runoff that this RWHs store for each of the proposed systems

Table 2 Homogeneous watersheds within the urban area of Arak (4*)

\begin{tabular}{llllll}
\hline $\begin{array}{l}\text { Homogeneous } \\
\text { group }\end{array}$ & 1 & 2 & 3 & 4 & 5 \\
\hline $\begin{array}{l}\text { Watershed } \\
\text { number }\end{array}$ & $\begin{array}{c}5,6,10,11,12, \\
14\end{array}$ & $2,4^{*}$ & $7,9,13,15,16$ & 1,8 & 3 \\
\hline
\end{tabular}

*The urban area of Arak (4*)
Table 4 The initial recommended investment in RWHS

\begin{tabular}{lllll}
\hline RWH & Micro basin & Water tank & French drain & Mulch \\
\hline $\begin{array}{c}\text { Initial invest- } \\
\text { ment (\$) }\end{array}$ & 0.25 & 50 & 1.75 & 0.116 \\
\hline
\end{tabular}

were calculated (Table 5). Also, Table 5 presents the profitability due to implementation of water extraction systems based on runoff volume. Then the efficiency of RWHSs was determined given the rate of benefit to cost (Table 6). This table declares the rate of RWHSs yields in each of the homogenous watersheds.

Since all of the proposed RWHSs need maintenance, this cost was calculated annually and presented in Table 7.

Table 8 presents the best suitable RWHSs for homogenous watersheds according to results of AHP with Expert Choice software. Thus, prioritizing of RWHSs in any homogeneous unit was done.

\section{Discussion}

In this research, the best RWHS was determined using the AHP with Expert Choice 11 software for homogenous watersheds overlooking the Arak city. To do this, five options were suggested for RWHSs which include existing situation, Micro Basin, Water Tank, French Drain and Mulch with five measures which include the initial investment (execution cost), the efficiency of RWHSs (the rate of benefit to cost ratio), maintenance costs, ease of implementation and water extraction capability.

As Table 8 shows, for groups of 1, 3 and 4 that include the more of the study area, the priority is that Mulch and the Micro Basin have the second priority. Since the maximum land-use area of the watersheds of these three groups (except watershed number 12) allocated to arid and semiarid ranges that their geological structure is mainly slit and sandstone that belongs to hydrologic group of $\mathrm{C}$, and hence, the execution of Mulch system in this area in addition to important reductions in soil evaporation also increases the soil humidity and finally encourages the vegetation of the study area. Due to the poor condition of vegetation in the study area,

Table 3 Runoff volume of the maximum 24-hour precipitation with a return period of 100 years (design storm)

\begin{tabular}{|c|c|c|c|c|c|c|c|c|c|c|c|c|c|c|c|c|}
\hline Watershed number & 1 & 2 & 3 & 4 & 5 & 6 & 7 & 8 & 9 & 10 & 11 & 12 & 13 & 14 & 15 & 16 \\
\hline $\begin{array}{l}\text { Runoff volume in } \\
\text { total area (million } \\
\text { cubic meter) }\end{array}$ & 541.5 & 38 & $11,324.9$ & 1393.4 & 45.3 & 129.9 & 237.3 & 514.1 & 139.4 & 151 & 62.1 & 404 & 196.3 & 79.2 & 93.2 & 118.6 \\
\hline $\begin{array}{l}\text { Runoff volume } \\
\text { for one hectare } \\
\text { (cubic meter) }\end{array}$ & 372 & 337 & 286 & 469 & 425 & 331 & 325 & 328 & 294 & 317 & 313 & 233 & 320 & 350 & 371 & 335 \\
\hline
\end{tabular}


Table 5 The benefits of the proposed RWHSs

\begin{tabular}{|c|c|c|c|c|}
\hline $\begin{array}{l}\text { Homog- } \\
\text { enous } \\
\text { groups }\end{array}$ & $\begin{array}{l}\text { The average amount of rainfall } \\
\text { runoff for each design storm }\left(\mathrm{M}^{3}\right)\end{array}$ & The proposed RWHSs & Stored runoff $\left(\mathrm{M}^{3}\right)$ & Benefit (\$) \\
\hline \multirow[t]{4}{*}{1} & \multirow[t]{4}{*}{328.17} & Micro basin & 147.68 & 0.113233 \\
\hline & & Water tank & 328.17 & 0.251467 \\
\hline & & French drain & 109.39 & 0.083867 \\
\hline & & Mulch & 109.39 & 0.083867 \\
\hline \multirow[t]{4}{*}{2} & \multirow[t]{4}{*}{403} & Micro basin & 181.35 & 0.139033 \\
\hline & & Water tank & 403 & 0.309867 \\
\hline & & French drain & 134.33 & 0.103 \\
\hline & & Mulch & 134.33 & 0.103 \\
\hline \multirow[t]{4}{*}{3} & \multirow[t]{4}{*}{329} & Micro basin & 14.05 & 0.1135 \\
\hline & & Water tank & 329 & 0.252233 \\
\hline & & French drain & 109.67 & 0.084067 \\
\hline & & Mulch & 109.67 & 0.084067 \\
\hline \multirow[t]{4}{*}{4} & \multirow[t]{4}{*}{233.33} & Micro basin & 105 & 0.0805 \\
\hline & & Water tank & 233.33 & 0.178633 \\
\hline & & French drain & 77.78 & 0.059633 \\
\hline & & Mulch & 77.78 & 0.059633 \\
\hline \multirow[t]{4}{*}{5} & \multirow[t]{4}{*}{286} & Micro basin & 128.7 & 0.098667 \\
\hline & & Water tank & 286 & 0.219267 \\
\hline & & French drain & 95.33 & 0.0731 \\
\hline & & Mulch & 95.33 & 0.0731 \\
\hline
\end{tabular}

Table 6 The efficiency of the proposed RWHSs

\begin{tabular}{lll}
\hline $\begin{array}{l}\text { Homogenous } \\
\text { groups }\end{array}$ & The proposed RWHSs & $\begin{array}{l}\text { Efficiency (the } \\
\text { rate of benefit to } \\
\text { cost) }\end{array}$ \\
\hline 1 & Micro basin & 45.71 \\
& Water tank & 0.5 \\
& French drain & 4.78 \\
& Mulch & 72.3 \\
& Micro basin & 56.14 \\
& Water tank & 0.62 \\
& French drain & 5.88 \\
& Mulch & 88.78 \\
& Micro basin & 45.83 \\
& Water tank & 0.5 \\
& French drain & 4.8 \\
& Mulch & 72.48 \\
& Micro basin & 32.5 \\
& Water tank & 0.36 \\
& French drain & 3.4 \\
& Mulch & $40 / 51$ \\
& Micro basin & 0.098667 \\
& Water tank & 0.219267 \\
& French drain & 0.0731 \\
& Mulch & 0.0731 \\
\hline & &
\end{tabular}

Table 7 Maintenance cost of the proposed RWHSs

\begin{tabular}{ll}
\hline The proposed RWHSs & $\begin{array}{l}\text { Maintenance } \\
\text { costs per cubic } \\
(\$)\end{array}$ \\
\hline Micro basin & 2 \\
Water tank & 0 \\
French drain & 2.53 \\
Mulch & 0.3833 \\
\hline
\end{tabular}

according to the Wang et al. (2009) it is better to use sandygravel mulch. Also, the Micro Basin as the second priority, an area with calm slope, can act as a supplementary system.

Group five (Ghare kahriz) that comprises watershed no. 3, RWHS of Micro Basin, as an optimum system has the first priority, and mulch is in the second priority. This prioritization in the Ghara kahriz is such that the maximum land-use area of the watersheds of this group allocated to dry land and rangelands that their geological structure is mainly shale, sandstone, and orbitolina lime (Fig. 3). But, the maximum area of this watershed geological unit belongs to alluvial terraces that include dry farming, irrigated agriculture and orchards and to somewhat residential-industrial land uses that are in hydrologic group B. Hence, according to the results of $\mathrm{Li}$ et al. (2005), with the implementation of the Micro Basin system in the Ghara kahriz watershed, 
Table 8 The prioritization of RWHSs based on AHP

\begin{tabular}{|c|c|c|c|c|c|}
\hline Homogenous groups & 1 & 2 & 3 & 4 & 5 \\
\hline Watershed number & $5,6,10,11,12,14$ & 2,4 & $7,9,13,15,16$ & 1,8 & 3 \\
\hline The first priority & Mulch & Water tank & Mulch & Mulch & Micro basin \\
\hline The second priority & Micro basin & Existing situation & Micro basin & Micro basin & Mulch \\
\hline The third priority & Existing situation & Mulch & Existing situation & Existing situation & Existing situation \\
\hline The fourth priority & French drain & Micro basin & French drain & French drain & French drain \\
\hline The fifth priority & Water tank & French drain & Water Tank & Water tank & Water tank \\
\hline
\end{tabular}

Fig. 3 The geology map of the region

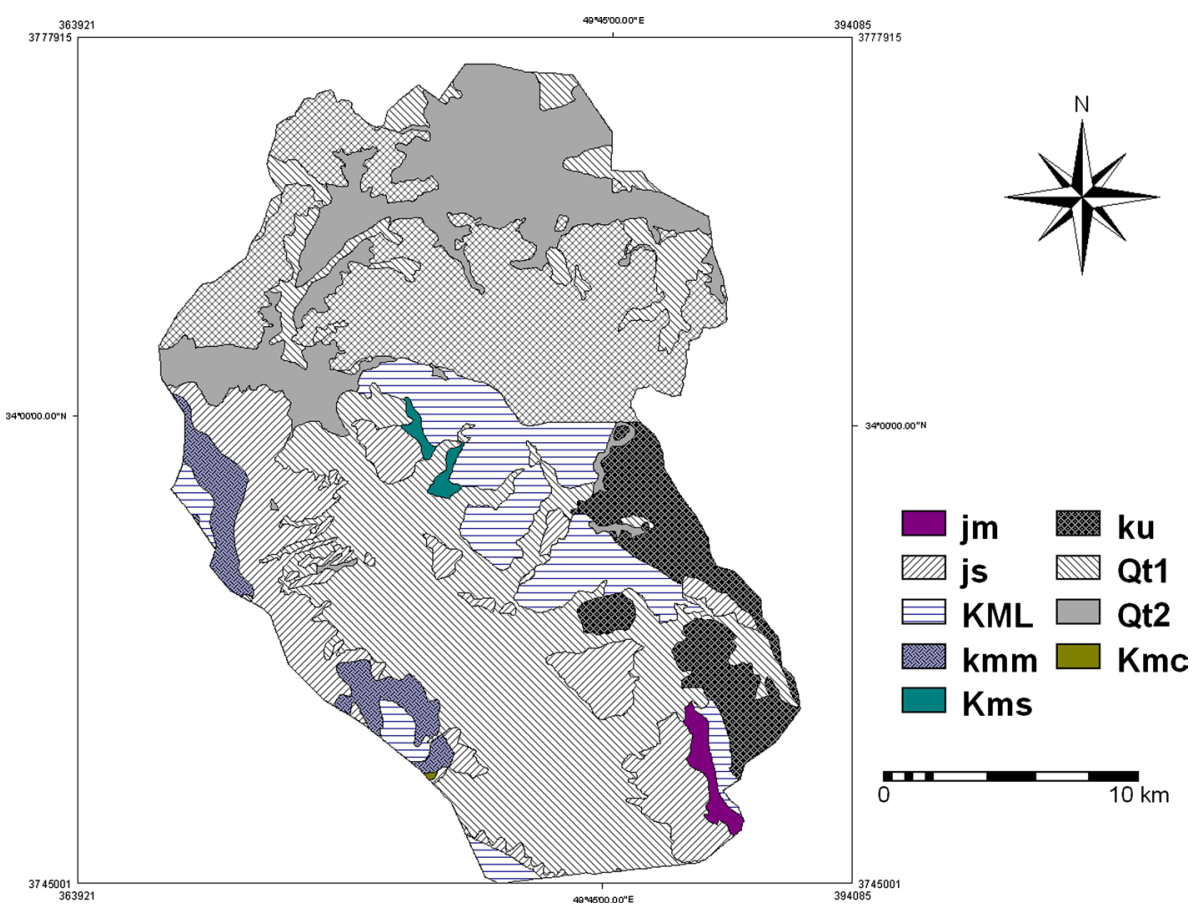

runoff can be collected at low and relatively flat slopes, and this in addition to resolving the shortage of water for agricultural and horticultural land irrigated raises also the cultivation area. Also, the second priority of this system which belongs to Mulch system is recommended for rangelands, because the rangelands of the Ghara kahriz watershed are similar to watersheds 1, 3 and 4, and hence, use of the Mulch system can increase soil moisture and also make to range improvement.

Finally, for group 2 (combination of watersheds 2 and 4 ), use of water tanks for the optimum system is the first priority and existing situation is the second priority.

\section{Conclusion}

Since water tanks are fed up with the runoff from roof installations, the implementation of these RWHSs in the Arak urban watershed could be a good supplemental source of water for non-potable uses. Also, watershed 2 with an area of $1 \mathrm{~km}^{2}$ located in the south of the Arak urban watershed has these conditions as well. Nevertheless, the size of Water Tanks must be determined based on rainfall intensity and the cost of implementing the system. Because the total cost per unit of tank capacity decreases with the increasing in tank capacity and also the factors such as the average annual precipitation and rainfall intensity affect the size of Water Tanks directly. With the implementation of this system by adding a new water source, in addition to reducing pressure on groundwater on the outskirts of the Arak city, transfer of water from the Kamal Saleh dam can be better managed. As noted previously, the mentioned transition plan could not be considered as a long-term water supply for all households in the Arak city and given the very high cost of the project, overuse of the mentioned water supply source does not cost for nonpotable purposes. Thus, with the implementation of the Water Tank system, in the Arak urban watershed, transfer of water from the Kamal Saleh dam can be better managed for many years. 
Given the above, implementation of optimum RWHSs for the watersheds overlooking to Arak city requires careful and comprehensive planning. Also, the public acceptance and the degree of satisfaction among them have an important role in the successful implementation of these systems. Finally, it should be noted that RWHSs is an important technique for increasing water supply and also for its proper and sound management. Also, the scientifically structured and systematic approach of this technique, needs to be ensured with its maximum benefits.

Acknowledgements We thank Markazi Regional Water authority for providing the data for discharge and sediment and for helping us with the data preprocessing.

\section{Compliance with ethical standards}

Conflict of interest The authors declare that they have no competing interests.

Open Access This article is distributed under the terms of the Creative Commons Attribution 4.0 International License (http://creativeco mmons.org/licenses/by/4.0/), which permits unrestricted use, distribution, and reproduction in any medium, provided you give appropriate credit to the original author(s) and the source, provide a link to the Creative Commons license, and indicate if changes were made.

\section{References}

Abdulla FA, Al-Shareef AW (2009) Roof rainwater harvesting systems for household water supply in Jordan. Desalination 243:195-207. https://doi.org/10.1016/j.desal.2008.05.013

Ahmed AOC, Nagasawa R, Hattori K, Chongo D, Perveen MF (2007) Analytical hierarchy process in conjunction with GIS for identification of suitable sites for water harvesting in the oasis areas: a case study of the oasis zone of Adrar, northern Mauritania. J Appl Sci 7(19):2911-2917

Berndtsson JC (2010) Green roof performance towards management of runoff water quantity and quality: a review. Ecol Eng 36:351-360

Berndtsson JC, Emilsson T, Bengtsson L (2006) The influence of extensive vegetated roofs on runoff water quality. Sci Total Environ 355:48-63

Boers TM, Asher JB (1982) A review of rainwater harvesting. Agric Water Manag 5:145-158

Butler D, Memon FA, Makropoulos C, Southall A, Clarke L (2010) WaND: guidance on water cycle management for new developments. CIRIA Report C690. CIRIA, London, ISBN 9780860176909

Daigger GT (2009) Evolving urban water and residuals management paradigms: water reclamation and reuse, decentralization, and resource recovery. Water Environ Res 81(8):809-822. http://www. jstor.org/stable/40575405

De Winnaar GD, Jewitt GPW, Horan M (2007) A GIS-based approach for identifying potential runoff harvesting sites in the Thukela River basin, South Africa. Phys Chem Earth 32(15-18):10581067. https://doi.org/10.1016/j.pce.2007.07.009

Farreny R, Morales-Pinzon T, Guisasola A, Taya C, Rieradevall J, Gabarrell X (2011) Roof selection for rainwater harvesting: quantity and quality assessments in Spain. Water Res 45:32453254. https://doi.org/10.1016/j.watres.2011.03.036

Fletcher TD, Deletic A, Mitchell VG, Hatt BE (2008) Reuse of urban runoff in Australia: a review of recent advances and remaining challenges. J Environ Qual 37:116-127

Foltz RC (2002) Iran's water crisis: cultural, political and ethical dimensions. J Agric Environ Ethic 15(4):357-380. https://doi. org/10.1023/A:1021268621490

Foundation S (2008) Solving the urban runoff problem a vision for the urban watershed Ventura, California, Campbell Foundation, Patagonia Inc., and others, $28 \mathrm{p}$

Groffman PE, Law NE, Belt KT, Band LE, Fisher GT (2004) Nitrogen fluxes and retention in urban watershed ecosystems. Ecosystems 7(4):393-403. https://doi.org/10.1007/s10021-003-0039-x

Hermann T, Schmida U (1999) Rainwater utilization in Germany: efficiency, dimensioning, hydraulic and environmental aspects. Urban Water 1(4):307-316. https://doi.org/10.1016/S1462 $-0758(00) 00024-8$

James Grant AT, McKinney NL, Ries R (2018) An approach to quantifying rainwater harvesting potential using imagery, geographic information systems (GIS) and LiDAR data. Water Sci Technol Water Supply 18(1):108-118. https://doi.org/10.2166/ ws. 2017.026

Jihad-Agriculture organization of Markazi provinces (2009) Integrated study of Gharahkahriz watershed, $6 \mathrm{p}$

Jones MP, Hunt WF (2010) Performance of rainwater harvesting systems in the southeastern United States. Resour Conserv Recycl 54:623-629. https://doi.org/10.1016/j.resconrec.2009.11.002

Khaleghi MR, Varvani J (2018a) Simulation of relationship between river discharge and sediment yield in the semi-arid river watersheds. Acta Geophys 66:109-119. https://doi.org/10.1007/s1160 0-018-0110-9

Khaleghi MR, Varvani J (2018b) Sediment rating curve parameters relationship with watershed, characteristics in the semiarid river watersheds. Arab J Sci Eng 43(7):3725-3737. https://doi. org/10.1007/s13369-018-3092-7

Khaleghi MR, Gholami V, Ghodusi J, Hosseini H (2011) Efficiency of the geomorphologic instantaneous unit hydrograph method in flood hydrograph simulation. Catena 87:163-171. https://doi. org/10.1016/j.catena.2011.04.005

Khaleghi MR, Ghodusi J, Ahmadi H (2014) Regional analysis using the geomorphologic instantaneous unit hydrograph (GIUH) method. Soil Water Res 9(1):25-30. https://doi.org/10.17221 133/2012-SWR

Kim LH, Kayhanian M, Zoh KD, Stenstrom MK (2005) Modeling of highway stormwater runoff. Sci Total Environ 348(1-3):1-18. https://doi.org/10.1016/j.scitotenv.2004.12.063

Lee JY, Bak G, Han M (2012) Quality of roof-harvested rainwater e Comparison of different roofing materials. Environ Pollut 162:422-429. https://doi.org/10.1016/j.envpol.2011.12.005

Li XY, Xie Z, Yan X (2004) Runoff characteristics of artificial catchment materials for rainwater harvesting in the semiarid regions of China. Agric Water Manag 65:211-224. https://doi. org/10.1016/j.agwat.2003.09.003

Li XY, Liu LY, Gao SY, Shi PJ, Zou XY, Zhang CL (2005) Micro catchment water harvesting for growing Tamarix ramosissima in the semiarid loess region of China. For Ecol Manag 214(13):111-117. https://doi.org/10.1016/j.foreco.2005.03.068

Liaw CH, Tsai YL (2004) Optimum storage volume of rooftop rainwater harvesting systems for domestic use. J Am Water Resour Assoc (JAWRA) 40(4):901-912. https://doi. org/10.1111/j.1752-1688.2004.tb01054.x

Lye DJ (2009) Rooftop runoff as a source of contamination: a review. Sci Total Environ 407(21):5429-5434. https://doi.org/10.1016/j. scitotenv.2009.07.011 
Mitchell VG (2007) How important is the selection of computational analysis method to the accuracy of rainwater tank behaviour modelling? Hydrol Process 21(21):2850-2861. https://doi. org/10.1002/hyp.6499

Moran A, Hunt B, Jennings G (2003) A North Carolina field study to evaluate green-roof runoff quantity, runoff quality, and plant growth. ASCE Conf Proc 118:335. https://doi. org/10.1061/40685(2003)335

Morton B (2002) Jordan Cove urban watershed project. UNI-Group USA, $4 \mathrm{p}$

Muthukrishnan S, Madge B, Selvakumar A, Field R, Sullivan D (2004) The use of best management practices (BMPs) in urban watersheds. EPA/600/R-04/184, $271 \mathrm{p}$

Mwenge Kahinda J, Lillie ESB, Taigbenu AE, Taute B, Boroto RJ (2008) Developing suitability maps for rainwater harvesting in South Africa. Phys Chem Earth Parts A/B/C 33(8-13):788-799. https://doi.org/10.1016/j.pce.2008.06.047

Obeidat M, Awawdeh M (2002) GIS-based multi-criteria analysis for mapping potential sites for rainwater harvesting in The Hamad basin, northeast Jordan. Jordan University of Science and Arts Irbid-Jordan, 29 p. http://repository.yu.edu.jo/handle/12345 $6789 / 822$

Oweis T, Hachum A (2006) Water harvesting and supplemental irrigation for improved water productivity of dry farming systems in West Asia and North Africa. Agric Water Manag 80(1-3):57-73. https://doi.org/10.1016/j.agwat.2005.07.004

Palla A, Gnecco I, Lanza LG (2011) Non-dimensional design parameters and performance assessment of rainwater harvesting systems. J Hydrol 401:65-76. https://doi.org/10.1016/j.jhydrol.2011.02.009

Perez-Pedini C, Limbrunner JF, Vogel RM (2005) Optimal location of infiltration-based best management practices for storm water management. J Water Resour Plan Manag 131(6):441-448. https ://doi.org/10.1061/(ASCE)0733-9496(2005)131:6(441)

Platt RH (2006) Urban watershed management sustainability, one stream at a time. Environ Sci Policy Sustain Dev 48(4):26-42. https://doi.org/10.3200/ENVT.48.4.26-42

Roy AH, Wenger SJ, Fletcher TD, Walsh CJ, Ladson AR, Shuster WD, Thurston HW, Brown RR (2008) Impediments and solutions to sustainable, watershed-scale urban storm water management: lessons from Australia and the United States. Environ Manag 42(2):344-359. https://doi.org/10.1007/s00267-008-9119-1

Saaty TL (1980) The analytical hierarchy process. McGraw Hill, New York

Saaty TL, Vargas GL (1991) Prediction, projection and forecasting. Kluwer Academic Publishers, Dordrecht

Saaty TL, Vargas GL (2001) Models, methods, concepts, and applications of the analytic hierarchy process. Kluwer Academic Publisher, Boston

Singh RG (2009) Landslide classification, characterization and susceptibility modeling in KwaZulu-Natal, M.SC thesis, pp 170. http:// hdl.handle.net/10539/7624

Teemusk A, Mander U (2007) Rainwater runoff quantity and quality performance from a green-roof: the effects of short-term rain events. Ecol Eng 30:271-277

Teimouri M, Graee P (2012) Evaluation of AHP and frequency ratio methods in landslide hazard zoning (case study: Bojnord urban watershed, Iran). Int Res J Appl Basic Sci 3(9):1978-1984
Van Roon M (2007) Water localization and reclamation: steps towards low impact urban design and development. J Environ Manag 83(4):437-447. https://doi.org/10.1016/j.jenvman.2006.04.008

Vialle C, Sablayrolles C, Lovera M, Huau MC, Montréjaud-Vignoles M (2011) Modelling of a roof runoff harvesting system: the use of rainwater for toilet flushing. Water Sci Technol Water Supply 11(2):151-158. https://doi.org/10.2166/ws.2011.031

Vialle C, Sablayrolles C, Lovera M, Huau MC, Jacob S, MontréjaudVignoles M (2012) Water quality monitoring and hydraulic evaluation of a household roof runoff harvesting system in France. Water Resour Manag 26(8):2233-2241. https://doi.org/10.1007/ s11269-012-0012-6

Vijayaraghavan K, Joshi UM, Balasubramanian R (2012) A field study to evaluate runoff quality from green roofs. Water Res 46(4):1337-1345. https://doi.org/10.1016/j.watres.2011.12.050

Wang Y, Xie Z, Malhi SS, Vera CL, Zhang Y, Guo Z (2011) Effects of gravel-sand mulch, plastic mulch and ridge and furrow rainfall harvesting system combinations on water use efficiency, soil temperature and watermelon yield in a semi-arid Loess Plateau of northwestern China. Agri Water Manag 101(1):88-92. https:// doi.org/10.1016/j.agwat.2011.09.006

Ward S, Memon FA, Butler D (2012) Performance of a large building rainwater harvesting system. Water Res 46:5127-5134. https:// doi.org/10.1016/j.watres.2012.06.043

Yalcin A, Reis S, Aydinoglu AC, Yomralioglu T (2011) A GIS-based comparative study of frequency ratio, analytical hierarchy process, bivariate statistics and logistics regression methods for landslide susceptibility mapping in Trabzon, NE Turkey. Catena 85:274287. https://doi.org/10.1016/j.catena.2011.01.014

Youn S, Chunga ES, Kangb WG, Sung JH (2012) Probabilistic estimation of the storage capacity of a rainwater harvesting system considering climate change. Resour Conserv Recycl 65:136-144. https://doi.org/10.1016/j.resconrec.2012.05.005

Zhang D, Gersberg RM, Wilhelm C, Voigt M (2009) Decentralized water management: Rainwater harvesting and greywater reuse in an urban area of Beijing, China. Urban Water J 6(5):375-385. https://doi.org/10.1080/15730620902934827

Zhang Q, Wang X, Hou P, Wan W, Li R, Ren Y, Ouyang Z (2014) Quality and seasonal variation of rainwater harvested from concrete, asphalt, ceramic tile and green roofs in Chongqing, China. J Environ Manag 132:178-187. https://doi.org/10.1016/j.jenvm an.2013.11.009

Zhu K, Zhang L, Hart W, Liu M, Chen H (2004) Quality issues in harvested rainwater in arid and semi-arid Loess Plateau of northern China. J Arid Environ 57(4):487-505. https://doi.org/10.1016/ S0140-1963(03)00118-6

Ziadat F, Bruggeman A, Oweis T, Haddad N, Mazahreh S, Sartawi W, Syuof M (2012) A participatory GIS approach for assessing land suitability for rainwater harvesting in an arid rangeland environment. Arid Land Res Manag 26:297-311. https://doi. org/10.1080/15324982.2012.709214

Publisher's Note Springer Nature remains neutral with regard to jurisdictional claims in published maps and institutional affiliations. 